\title{
IMPLEMENTASI PENDIDIKAN MASYARAKAT BERBASIS MASJID UNTUK MUSLIMAH DI DESA MATTOANGING KABUPATEN MAROS
}

\author{
Sri Ujiana Putri \\ Sekolah Tinggi Ilmu Islam dan Bahasa Arab (STIBA) Makassar \\ sri.ujiana@gmail.com
}

\section{Aswar}

STKIP Muhammadiyah Barru

aswaralgowi@gmail.com

Keywords:
Mattoangin Village,
Education, Muslim Women
Program

Keywords : ABSTRACT

The role of Muslim women in giving birth to an excellent generation is determined by the extent of the quality of the Muslim women themselves. The quality of these Muslim women will also be determined by the extent to which the quality of education and guidance they receive. This view is the background of the KKN program in Mattoanging Village which aimed to present various development programs for Muslim women based at the mosque as a form of efforts to improve the quality of civilization in the village of Mattoangin. The programs of development for Muslim women conducted are: 1) Taklim for Muslim; 2) the dirosa learning; 3) Learning for Qur'an recitation (Tahsin); 4) training for burial ritual; and 5) Muslimah Health Service. Each of them is described as follows. The results of these programs for Muslim women are expected to provide a good understanding of the importance of improving personal qualities as a Muslim woman who will give birth to an excellent nation.

\section{Kata kunci :}

Desa Mattoanging, Pendidikan, Program Muslimah.

\section{ABSTRAK}

Peran para muslimah dalam melahirkan generasi yang berkualitas sangat ditentukan oleh sejauh mana kualitas para muslimah itu sendiri. Kualitas para muslimah ini juga akan sangat ditentukan sejauh mana kualitas pendidikan dan pembinaan yang diperoleh. Berdasar pandangan inilah Mahasiswi KKN di Desa Mattoanging bertujuan untuk menghadirkan berbagai program pembinaan masyarakat muslimah yang berpusat di Masjid sebagai wujud ikhtiar dalam meningkatkan kualitas peradaban di desa Mattoangin. Adapun program pembinaan muslimah yang dilakukan adalah: 1) taklim muslimah; 2) Pembelajaran dirosah; 3) Perabaikan bacaan Al Qur'an (Tahsin); 4) Pelatihan penyelenggaraan jenazah; dan 5) Bakti Kesehatan Muslimah. Masing-masing diuraikan penjelasannya sebagai berikut. Hasil pembinaan muslimah ini diharapkan memberikan pemahaman yang baik tentang pentingnya meningkatkan kualitas personal sebagai seorang muslimah yang akan melahirkan generasi bangsa yang berkualitas 


\section{PENDAHULUAN}

\section{A. Profil Desa Mattoangin}

1. Sejarah Desa Mattoangin

Desa Mattoangin pada mulanya berada dalam distrik Kecamatan Simbang (sebelum menjadi kecematan), yang kemudian distrik Simbang berubah menjadi Kecamatan Bantimurung dan dimekarkan menjadi dua yakni wilayah Kecamatan Simbang dan Kecamatan Bantimurung. Hasil pemekaran Kecamatan tersebut memposisikan Desa Mattoangin berada dalam wilayah Kecamatan Bantimurung sampai saat ini. Desa Mattoangin sejak keberadaannya sudah pernah mengalami pemekaran Desa menjadi dua wilayah yaitu Desa Alatengae dan Desa Mattoangin yang terdiri dari lima Dusun.

Mattoangin bila diurai dalam bahasa Indonesia mengandung arti udara yang segar, dan salah satu Dusun menjadi pusat pemerintahan Desa Mattoangin berada di Dusun Bonti-Bonti hingga saat ini. Dalam sejarah penamaan Desa Mattoangin tidak terlepas dari sejarah penamaan kelima Dusun yaitu: 1) Dusun Bonti-Bonti; 2) Dusun Malewang; 3) Dusun Paranggi; 4) Dusun Moncongbori; 5) Dusun Katubung. Dasar sejarah inilah kelima Dusun tersebutsemuanya menggambarkan niat dan tujuan yang baik sehingga dengannya orang-orang tua terdahulu mereka sepakat member nama Desa Mattoangin menjadi Desa aman, maju, dan makmur.

\section{Kondisi Geografis, Demografis, dan Keadaan Iklim}

Secara geografis Desa Mattoangin merupakan salah satu dari enam Desa di Kecamatan Bantimurung Kabupaten Maros dan memiliki luas wilayah $\pm 10 \mathrm{Km} 2$ at au \pm 1000,00 Ha. Desa Mattoangin terletak $\pm 12 \mathrm{Km}$ dari Ibukota Kabupaten Maros, sedangkan $\pm 5 \mathrm{Km}$ dari Ibukota Kecamatan dengan batas-batas sebagai berikut :

a. Sebelah Utara dari Desa Tukamasea Kecamatan Bantimurung

b. Sebelah Timur dari Desa Mangeloreng Kecamatan Bantimurung

c. Sebelah Selatan dari Desa Alatengae Kecamatan Bantimurung

d. Sebelah Barat dari Kelurahan Boribellayya Kecamatan Turikale.

Adapun secara demografis Desa Mattoangin memiliki jumlah penduduk sebanyak 3.311 orang dengan rincian 1.610 orang laki-laki dan 1.701 Orang perempuan. Jumlah kepala keluarga sebanyak 925 KK dengan Kepadatan penduduk seluas 374,66 per KM. Desa Mattoangin memiliki Sembilan belas RT dan lima dusun yang terdiri dari dusun Bonti-bonti, dusun Malewang, Dusun Moncongbori, Dusun Katubung, dan Dusun Paranggi.

Keadaan iklim di Desa Mattoangin terdiri dari musim hujan dan musim kemarau. Musim hujan terjadi sekitar bulan November sampai Maret yang di mana curah hujan berkisar 347,00 mm. pada musim kemarau yang terjadi pada bulan Juni hingga Oktober. 
Adapun ditinjau dari segi topografi dan kontur tanahnya, teridentifikasi beberapa jenis lahan yang terdapat di Desa Mattoangin, yakni:

a. Desa/kelurahan dataran rendah seluas $150,00 \mathrm{Ha}$

b. Desa/kelurahan berbukit-bukit seluas $40,000 \mathrm{Ha}$

c. Desa/kelurahan dataran tinggi atau pegunungan seluas $190,00 \mathrm{Ha}$

d. Desa/kelurahan lereng gunung seluas 20,00 Ha

e. Desa/kelurahan bantaran sungai seluas $10,00 \mathrm{Ha}$

\section{Gambaran Aktivitas Masyarakat}

Mata pencaharian sehari-hari masyarakat adalah sebagian besar petani yang berdasarkan informasi akurat bahwa jumlah dari keluarga petani sebanyak 2000 orang, laki-laki 1500 orang dan perempuan 500 orang dengan luas lahan sawah 498,00 Ha. Adapun komoditas pangan yang dihasilkan pada tahun 2018 sebanyak 70,00 ton/ Ha. Selain komoditas bahan pangan, sebagian petani juga membudidayakan lahan perkebunan seperti buah-buahan dan jenis buah-buahan yang dibudidayakan adalah semangka dengan luas lahan 250,00 Ha. Para petani juga menjual hasil pangan dan buahbuahan itu melalui KUD dan sebagaiannya lagi tidak dijual. Selain petani, sebagian aktivitas masyarakat menggeluti bidang peternakan dengan luas tanaman pakan peternak 3,00 Ha, pemasaran hasil ternaknya ke beberapa titik, seperti dijual ke pasar, melalui KUD, melalui tengkulak, melalui pengecer, dijual ke lumbung desa atau kelurahan, ataupun sama sekali tidak dijual. Selebihnya yang tercantum resmi sesuai dengan data mata pencaharian penduduk adalah pegawai, karyawan pabrik teh gelas, pedagang dan tukang galian batu marmer, dll.

Sebagaian masyarakat merangkap beberapa pekerjaan seperti pada pagi hari sebagai pedagang keliling menjual makanan khas bugis ke beberapa dusun atau bahkan ke desa lain. Setelah itu mereka mengambil dan memangkas beberapa rumput untuk makanan ternaknya, kemudian mereka lanjut sibuk mengurus dan mengolah sawahnya, kalau sedang lowong biasanya masyarakat rela mengajukan diri sebagai kuli bangunan hanya untuk memenuhi kebutuhan hidupnya. Jadi dapat disimpulkan bahwa masyarakat desa Mattoangin benar-benar memprioritaskan kebutuhan hidupnya dengan berbagai pekerjaan.

\section{Lembaga Pendidikan, Kesehatan, dan Kemasyarakatan}

Desa Mattoangin memiliki sekolah yang sudah terakreditasi kepemilikan pemerintah dan desa itu sendiri. Adapun tenaga pengajar secara keseluruhan 27 orang dengan kapasitas 270 siswa. Selain itu, pendidikan keagamaan seperti yayasan atau pesantren pendidikan non format (kursus) tidak ada. Jumlah anggota masyarakat yang berusia di bawah umur enam tahun yang belum sekolah atau lembaga apapun yang 
berbasis pendidikan sebanyak 267 orang dengan penjabaran laki-laki 135 orang dan perempuan 132 orang.

Berdasarkan jumlah sekolah dan masyarakat yang terdapat di desa Mattoangin sudah memenuhi kebutuhan pendidikan. Akan tetapi, yang menjadi permasalahan adalah kurangnya tenaga pengajar yang ahli dibidangnya, fasilitas sekolah serta sarana prasarana belajar mengajar belum memadai. Dan tidak sedikit masyarakat lebih memilih untuk putus sekolah disebabkan karena faktor biaya hidup yang kurang mencukupi. Ditinjau dari jarak sekolah dan rumah masyarakat, masih banyak orangtua menyekolahkan anaknya di luar desa hal ini ditinjau dari jarak sekolah dan rumahnya.

Adapun berkaitan dengan lembaga kesehatan, hasil odentifikasi mahasiswa menunjukkan bahwa Desa Matoangin memiliki puskesmas Pembantu sebanyak 1 unit, rumah bersalin 1 unit, posyandu 5 unit, dari segi ketenaga kerjaannya ialah jumlah dukun salin terlatih sebanyak 3 orang dan bidan 4 sebanyak orang. Jumlah lembaga kesehatan yang terdapat di desa Mattoangin belum memenuhi untuk menunjang kesehatan masyarakat desa. Fasilitas dan tenaga medis yang kurang serta pelayanan yang belum maksimal. Sehingga, masyarakat belum bisa terpenuhi dalam segi kesehatan.

Untuk lembaga Kemasyarakatan yang ada di Desa Mattoangin adalah kelompok tani dan Badan Usaha Milik Desa. Dasar hukum pembentukan berdasarkan keputusan Walikota/Bupati. Ruang lingkup kegiatan yakni, tanaman pangan dan semangka. Terdapat sejumlah 12 kelompok tani yang masing-masing dipimpin oleh 1 orang ketua kelompok. Jumlah keseluruhan anggota masyarakat yang tergabung dalam kelompok tani adalah 605 orang.

\section{B. Masjid Sebagai Pusat Pendidikan Muslimah}

Masjid sejak lama telah menjadi tempat pembinaan dan pendidikan bagi ummat Islam dan tidak hanya berfungsi sebagai tempat beribadah mahdhah seperti salat dan zikir semata. Lebih jauh dari itu, bahkan masjid memiliki fungsi yang lebih luas sebagai pusat kegiatan sosial kemasyarakatan. Di zaman dahul masjid juga berfungsi sebagai barak sekaligus benteng pertahanan militer, tempat pengobatan para korban perang, tempat mendamaikan dan menyelesaikan sengketa, tempat menerima utusan delegasi/tamu, serta sebagai pusat penerangan dan pembelaan agama.

Masjid sebagai pusat Pembinaan dan Pendidikan telah dimulai sejak zaman Rasulullah. ${ }^{1}$ Realitas sejarah menunjukkan bahwa ummat Islam menjalankan masjid dalam fungsinya yang luas dan beragam, masjid tidak hanya berfungsi sebagai tempat ibadah saja. ${ }^{2}$ Dari pembinaan yang dilakukan Rasulullah di masjid itu lahirlah tokoh-

\footnotetext{
${ }^{1}$ Cucu Nurjamilah. (2017). Pemberdayaan Masyarakat Berbasis Masjid dalam Perspektif Dakwah Nabi saw. Journal of Islamic Studies and Humanities, 1(1), 93-119. Hal 93

${ }^{2}$ Istikhori. (2017). Pemikiran Abd Al-Rahman Al-Nahlawi Tentang Pendidikan Masyarakat Berbasis Masjid (Studi Kitab Ushul Al-Tarbiyah Al-Islamiyyah wa Asalibuha: Fi Al-Bait wa Al-Madrasah wa AlMujtama). Edukasi Islami: Jurnal Pendidikan Islam, 6(02), 20. Hal. 1
} 
tokoh yang berjasa dalam pengembangan Islam ke seantero dunia. Masjid menjadi tempat Rasulullah untuk mendidik umat Islam dari segala umur dan jenis kelamin; dewasa, remaja, anak-anak, baik laki-laki maupun perempuan. Bagi orang dewasa, mereka memanfaatkan masjid untuk tempat belajar al-Quran, hadits, fikih, dasar-dasar agama, bahasa dan sastra Arab. Sementara bagi wanita, mereka mempelajari al-Quran, hadits, dasar-dasar Islam dan ketrampilan menenun atau memintal, dengan frekuensi seminggu sekali. Sementara anak-anak belajar di serambi masjid dengan materi alQuran, agama, bahasa Arab, berhitung, ketrampilan berkuda, memanah dan berenang. ${ }^{3}$

Oleh sebab itu masjid seharusnya berfungsi kembalisebagai pusat peradaban. umat Islam perlu memakmurkan masjid, mengembalikannya kepada fungsinya yang sesungguhnya, sebagaimana yang perintahkan oleh Allah SWT dalam firman-Nya, "Hanya yang memakmurkan masjid-masjid Allah ialah orang-orang yang beriman kepada Allah dan Hari kemudian, serta tetap mendirikan salat, menunaikan zakat, dan tidak takut (kepada siapa pun) selain kepada Allah, maka merekalah orang-orang yang diharapkan termasuk golongan orang-orang yang mendapat petunjuk."(QS At-Taubah : 18).

Secara realitas masjid-masjid selama ini memang kebanyakan hanya difungsikan sebagai tempat ibadah secara ritual, maka dengan terimplementasinya kegiatan dakwah bi hal melalui program Posdaya berbasis masjid, ke depan masjid dapat menjadi sentra kegiatan kemasyarakatan mulai kegiatan ibadah, kegiatan pendidikan, kegiatan wanita, kegiatan koperasi, kegiatan kesehatan, bahkan kegiatan jurnalistik sebagai media dahwah sangat efektif dalam menjawab semua permasalahan yang terdapat di tengahtengah masyarakat. ${ }^{4}$

Semangat inilah yang mendasari mahasiswi KKN STIBA Makassar dalam implemetasi program KKN dengan menjadikan masjid sebagai pusat pendidikan dan pembinaan keislaman untuk masyarakat khususnya kaum muslimah yang ada di Desa Mattoangin. Sejarah mencatat bahwa Masjid dan Muslimah memiliki peran penting dalam mewujudkan peradaban yang gemilang. Sebaliknya tidak memberikan perhatian pada masjid serta pembinaan Muslimah menjadi salah satu gerbang keruntuhan peradaban Islam yang gemilang.

\section{PEMBAHASAN}

\section{A. Pendidikan Masyarakat Berbasis Masjid}

Istilah masjid berasal dari bahasa arab yang berarti tempat untuk bersujud. Dalam pengertian luas, seluruh hamparan bumi ini sesungguhnya adalah masjid. Sebagaimana

\footnotetext{
${ }^{3}$ Idi, Abdullah dan Sukarto, Toto. 2006. Revitalisasi Pendidikan Islam, Yogyakarta: Tiara Wacana hal. 81

${ }^{4}$ Zakiyyah \& Arif Abdul Haqq. (2018). Strategi Dakwah Bil Hal Dalam Program Posdaya Berbasis Masjid. ORASI: Jurnal Dakwah dan Komunikasi, 9(1), 127-143. Hal 143
} 
sabda Rasulullah saw., "Seluruh bumi ini dijadikan untukku sebagai masjid (tempat bersujud untuk shalat) dan sebagai alat untuk bersuci" (HR. Bukhari). Dalam pengertian khusus, istilah masjid merujuk kepada sebuah bangunan yang digunakan sebagai tempat ibadah bagi umat muslim. Di Indonesia sendiri masjid dikenal dengan berbagai perisitilahan lainnya seperti, surau, mushalla, langgar, tajug. ${ }^{5}$

Keberadaan masjid sebagai bangunan ini menjadi sangat penting. Karena selain menjadi bukti tegaknya syiar islam di suatu wilayah, keberadaan masjid juga memegang peranan penting dalam pembinaan umat. Itulah kenapa hal pertama yang Rasulullah bangun saat pertama kali tiba di Madinah adalah masjid. Masjid juga perlu diisi dengan berbagai kegiatan yang meningkatkan kualitas imaniyah dengan berbagai aktifitas keagamaan. Karena itu, kesadaran diri dari masing-masing individu muslim untuk memakmurkan masjid yang telah dibangun. Dalam surat at-Taubah ayat 18, Allah swt. menegaskan bahwa memakmurkan masjid merupakan salah satu bukti kebenaran iman dalam hati seorang hamba. Rasulullah SAW juga menyebutkan bahwa salah satu golongan yang akan mendapat naungan Allah di hari kiamat kelak adalah seorang hamba yang hatinya selalu terpaut dengan masjid. (HR. Bukhari dan Muslim).

Masjid memiliki peran besar bagi masyarakat, sejatinya masjid adalah pusat peradaban bagi umat Islam. Selain itu, masih banyak peran masjid dalam pemberdayaan umat Islam, baik secara individu, sosial maupun dalam hubungan dengan kehidupan berbangsa dan bernegara. Beberapa peran masjid yang dapat difungsikan dan dihidupkan di tengah masyarakat antara lain adalah: ${ }^{6}$ 1) Masjid sebagai tempat ibadah dan spiritual; 2) Masjid sebagai pusat pendidikan dan pelatihan masyarakat; 3) Masjid sebagai pusat informasi dan komunikasi; 4) masjid sebagai tempat yang menjamin keamanan; 5) masjid sebagai balai kesehatan; 6) masjid sebagai tempat kaderisasi umat; 7) masjid sebagai pusat perekonomian; 8) masjid sebagai pusat kepustakaan; 9) masjid sebagai identitas dan bukti peradaban umat

\section{B. Program Pendidikan Muslimah Berbasis Masjid}

Kesadaran akan pentingnya memakmurkan masjid ini harus dimulai sejak dini, terutama para remaja dan pemuda generasi melenial yang sekarang cenderung mengabaikan hal ini. Kesadaran tersebut tentunya harus dimunculkan dari mereka melalui kegiatan-kegiatan dakwah, pengajian, dan majelis taklim. Muslimah memiliki peran strategis dalam implementasi berbagai program tersebut. Muslimah memegang peranan penting terhadap maju tidaknya sebuah peradaban. Dari sentuhan para muslimah yang terbina dengan baik akan terlahir generasi-generasi berkualitas yang

\footnotetext{
5 Syafe'i, M. (2016). Masjid dalam perspektif sejarah dan hukum Islam. Online).(http://file. upi. edu/Direktori/FPIPS/M_K_D_U/195504281988031makhmud_Syafe'i/Masjid_Dalam_Prespektif_Seja Rah_Dan_Hukum_Islam_(10_Halaman). pdf).

${ }^{6}$ Taufiqurrochman, R. " Pendidikan Masyarakat Berbasis Masjid, Jurnal Jurusan Pendidikan Bahasa Arab", Fakultas Ilmu Tarbiyah dan Keguruan UIN Maulana Malik Ibrahim Malang.
} 
dapat menjadi penentu arah angin masa depan bangsa. Tidak berlebihan jika ada ungkapan yang menyatakan bahwa perempuan adalah adalah tiang suatu negara. Upaya dan perhatian untuk meningkatkan kualitas muslimah dapat dilakukan dengan berbagai program pendidikan dan pemberdayaan perempuan di tengah masyarakat pada semua lapisan jenjang (Desa hingga Provinsi). Pemberdayaan perempuan memiliki posisi urgen dalam pembangunan di dalam masyarakat. ${ }^{7}$ Selain itu program pendidikan, pembinaan, dan pemberdayaan perempuan di suatu komunitas masyarakat dapat berfungsi sebagai wadah untuk menumbuhkan sikap kritis perubahan ke arah yang lebih baik.

Islam adalah agama yang begitu menjunjung tinggi kaum perempuan. Kedudukan perempuan di mata Islam sangat terjaga dan memiliki posisi yang mulia. Begitu mulianya kaum perempuan, Allah abadikan mereka dalam salah satu nama surat dalam Al qur'an. Di dalam Al Qur'an juga terdapat sosok-sosok tauladan perempuan yang memiliki ketangguhan dan kualitas keimanan yang tinggi. Di masa peradaban Islam, kaum perempuan memiliki peranan yang tak bisa dipandang sebelah mata. Sebut saja, Khadijah ra, Istri tercinta Baginda Nabi saw. Beliaulah salah satu sumber kekuatan Rasulullah dalam mengemban risalah Islam dan pendukung setia Rasulullah berdakwah dalam suka maupun duka. Ada lagi Al Khansa, sosok ibu tangguh di zamannya yang rela melepas anaknya pergi berjihad hingga keempat putranya menjemput syahid di medan perang. Di masa para shahabat, ada sosok shahabiyah tegas dalam mengadili, dialah Al Syifa', seorang qadhi hisbah di masa Khalifah Umar bin Khattab. Dan masih banyak lagi kisah shahabiyah memiliki peran besar dalam peradaban Islam.

Peran para muslimah dalam melahirkan generasi yang berkualitas sangat ditentukan oleh sejauh mana kualitas para muslimah itu sendiri. Kualitas para muslimah ini juga akan sangat ditentukan sejauh mana kualitas pendidikan dan pembinaan yang diperoleh. Berdasar pandangan inilah Mahasiswi KKN di Desa Mattoangin berikhtiar menghadirkan berbagai program pembinaan masyarakat muslimah yang berpusat di Masjid sebagai wujud ikhtiar dalam meningkatkan kualitas peradaban di desa Mattoangin sekaligus menjadi upaya ikhtiar untuk memberdayakan kaum muslimah yang ada di desa Mattoangin.

Program pembinaan, pendidikan, dan pemberdayaan bagi masyarakat dapat diselenggarakan secara formal, non formal, dan informal. ${ }^{8}$ Pada penelitian ini fokus diselenggarakan secara informal dan dikhususkan untuk muslimah yang ada di Desa Mattoangin. Adapun program pembinaan muslimah yang dilakukan adalah: 1) taklim muslimah; 2) Pembelajaran dirosah; 3) Perabaikan bacaan Al Qur'an (Tahsin); 4)

\footnotetext{
${ }^{7}$ Rodiyah, R. R. (2018). Alternatif Pemberantasan Buta Aksara Bagi Kaum Perempuan Berbasis Masjid. Jurnal Ilmiah Syi'ar, 18(2), 1-7. Hal.2

8 Sujian Suretno, Aceng Zakaria, Ayub Pardian, Iwan Ginawan. (2020). Implementasi Pendidikan Masyarakat Berbasis Masjid di Islamic Center Palm Raya Melalui Kegiatan Pengabdian Kepada Masyarakat di Kelurahan Bubulak, Kecamatan Bogor Barat, Kota Bogor. Khidmatul Ummah: Jurnal Pengabdian Kepada Masyarakat, 1(01), 66-83. Hal. 68
} 
WAHATUL MUJTAMA': Jurnal Pengabdian Masyarakat

Vol. 1, No. 2 (2020) : Hal. 129-141

Website: https://journal.stiba.ac.id

Pelatihan penyelenggaraan jenazah; dan 5) Bakti Kesehatan Muslimah. Masing-masing diuraikan penjelasannya sebagai berikut.

\section{1) Taklim Muslimah}

Taklim muslimah merupakan salah satu program kerja mahasiswi KKN angkatan III Stiba Makassar. Kegiatan ini dibentuk dari hasil silturrahim dengan warga sekitar. Tujuan kegiatan dari taklim muslimah adalah memberikan materi dan pencerahan, menambah wawasan tentang keislaman, serta menigkatkan iman masyarakat mattoangin khususnya muslimah.

Pengalaman yang paling menarik pada saat taklim adalah besarnya rasa ingin tau para muslimah, sehingga banyak pertanyaan yang muncul berdasarkan yang dialami dalam keseharian mereka. Faktor Pendukung dalam kegiatan ini adalah tingginya semangat muslimah menghadiri ta'lim dan mereka merasa butuh dengan taklim yang mahasiswi adakan, melihat sangat banyak pertanyaan-pertanyaan menarik baik sesuai tema maupun yang tidak, pun juga dengan tempat yang disediakan sangat layak. Adapun kendala-kendala yang terjadi adalah naik turunnya kehadiran peserta dan waktu taklim yang disepakati sering berubah-ubah;
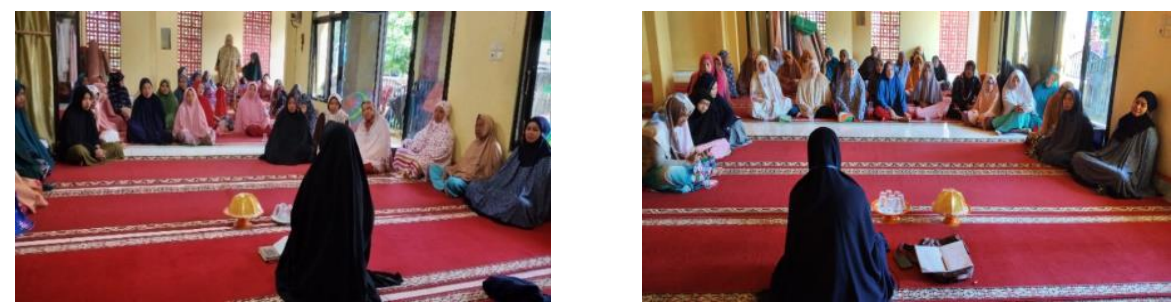

\section{Gambar 1. Kegiatan Taklim Muslimah}

\section{2) Pembelajaran DIROSA}

Pembelajaran dirosah adalah salah satu progam mahasiswa KKN angkatan III tahun 2020 STIBA Makassar. Kegiatan ini untuk memperbaiki bacaan al-Quran pada masyarakat desa Majannang dengan menggunakan metode pengajaran Dirosa, dengan menggunakan buku rujukan Dirosa. Sasaran pembelajaran yaitu mengajarkan bagaimana mengucapkan huruf dengan benar sesuai makhārijul hurufnya dan mengajarkan hukum-hukum tajwid secara singkat dan mudah. Adapun tujuan dari program kerja ini yaitu, 1) untuk memahamkan kepada masyarakat tentang pentingnya mempelajari al-Quran; 2) sebagai wasilah silaturahmi antara masyarakat desa Mattoangin dengan mahasiswa KKN STIBA Makassar; 3) memperbaiki bacaan al-Quran yang masih keliru pada masyarakat desa Mattoangin; 4) menambahkan wawasan keislaman pada masyarakat desa Mattoangin; 5) menambah semangat masyarakat untuk senantiasa memperbanyak membaca, mentadaburi, dan mengamalkan al-Quran; 6) menghasilkan 
kader penerus dalam hal pembinaan serta pengajaran baca tulis al-Quran (BTQ) yang nantinya bekesinambungan.

Pengalaman yang paling menarik pada saat proses mengajar dirosa ketika ibu-ibu sulit melafaskan huruf-huruf hijaiyyah sesuai dengan mahrajnya sehingga terkadang ibuibu menyebutkan kata pada buku dirosah yang mirip dengan bahasa bugis, misalnya syaraba, karna kesusahan maka ibu itu mengatakan sarebba yang berarti minuman jahe. Kegiatan dirosa sangat mendapat respon dari masyarakat di Desa Mattoangin karena sebelumnya mereka telah belajar dirosa dari KKN STIBA Makassar sebelum angkatan III. Meski demikian, terdapat beberap kendala yang juga dihadapai, seperti adanya kendala di beberapa dusun pada pekan pertama kedatangan KKN III STIBA Makassar masih ada yang baru memulai menanam padi sehingga pembentukan halaqah dirosa disebagian dusun baru dimulai di pekan ke tiga setelah kedatangan KKN III STIBA Makassar.
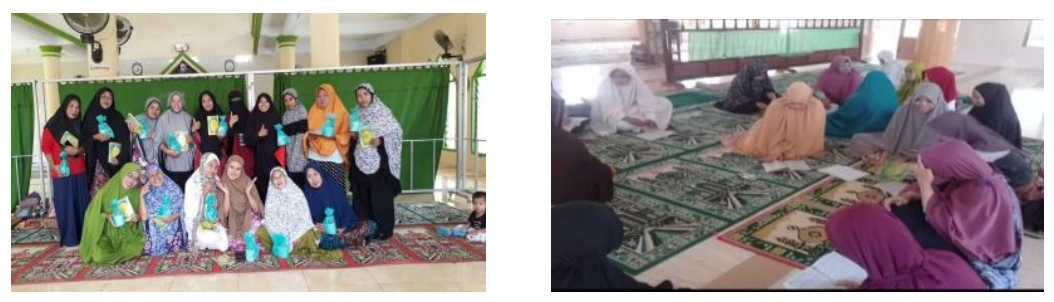

Gambar 2. Kegiatan Pembelajaran Dirosa

Pengalaman yang paling menarik pada saat proses mengajar dirosa ketika ibu-ibu sulit melafaskan huruf-huruf hijaiyyah sesuai dengan mahrajnya sehingga terkadang ibuibu menyebutkan kata pada buku dirosah yang mirip dengan bahasa bugis, misalnya syaraba, karna kesusahan maka ibu itu mengatakan sarebba yang berarti minuman jahe. Kegiatan dirosa sangat mendapat respon dari masyarakat di Desa Mattoangin karena sebelumnya mereka telah belajar dirosa dari KKN STIBA Makassar

\section{3) Perabaikan Bacaan Al Qur'an (Tahsin)}

Perbaikan bacaan (tahsin) adalah salah satu progam mahasiswa KKN angkatan III tahun 2020 STIBA Makassar. Sasaran dari kegiatan ini adalah memperbaiki bacaan muslimah yang sudah bisa mengaji. Halaqah tahsin baru dibentuk pada KKN III STIBA Makassar tahun ini. Dibentuk melalui silaturahmi kepada masyrakat. Adapun beberapa hal yang dipelajari dalam halaqah tahsin adalah Tadarrus, Perbaikan bacaan, Penjelasan tajwid, Motivasi memepelajari alqur'an dan hal-hal yang berkaitan dengannya. Kegiatan ini bertujuan untuk memperbaiki bacaan qur'an para muslimah, serta menjadi ajang silaturrahim antaramahasiswi KKN dengan muslimah di desa Mattoangin.

Pengalaman yang paling menarik pada saat mengajar tahsin ketika ibu-ibu merasa merasa senang mengetahui sesuatu yang baru saat belajar. Seperti perbedaan penyebutan 
WAHATUL MUJTAMA': Jurnal Pengabdian Masyarakat

Vol. 1, No. 2 (2020) : Hal. 129-141

Website: https://journal.stiba.ac.id

huruf $ص, ث$, شyang ternyata berbeda menunjukkan bahwa mereka sangat butuh akan kegiatan ini. Belajar tahsin (perbaikan bacaan alqur'an) mendapat sambutan baik dari ibu-ibu. Terutama ibu-ibu yang telah menyelesaikan dirosah dan guru tpa. Sebagai sarana dalam melancarkan dan perbaikan bacaan alqur'an. Adapun kendala kegiatan ini adalah Lesibukan peserta sehingga sulit menentukan waktu belajar dan banyaknya kegiatan mahasiswi KKN sehingga kadang kesulitan mengikuti waktu peserta.

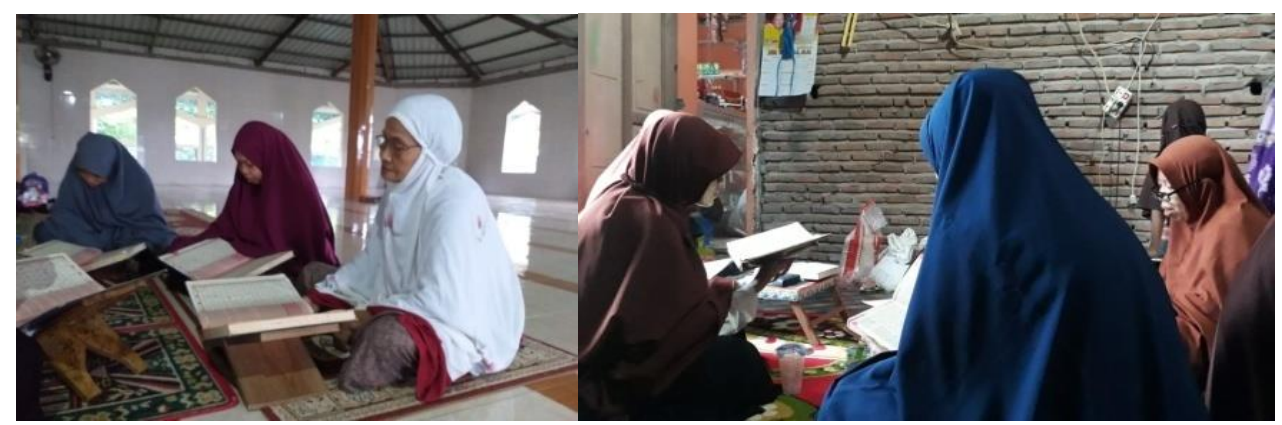

\section{Gambar 3. Perbaikan Bacaan Al Qur’an Muslimah (Tahsin)}

\section{4) Pelatihan Penyelenggaraan Jenazah}

Pelatihan penyelenggaraan jenazah adalah salah satu progam mahasiswa KKN angkatan III tahun 2020 STIBA Makassar. Kegiatan ini dikhususkan untuk muslimah, dilaksanakan satu kali dalam masa pengabdian KKN yang temanya berkaitan tentang kematian dan Jenazah, Adapun tujuan dari program kerja ini adalah untuk membantu masyarakat dalam memahami ilmu agama sesuai dengan hadist dan al qur'an serta menambah wawasan keislaman bagi warga masyarakat di desa Mattoangin terutama dalam tatacara penyelenggaraan jenazah sesuai sunnah. Besarnya rasa keingintahuan para muslimah mengenai cara pelaksanaan dan praktek dari mulai memandikan jenazah sampai mengkafaninya dan antusias para muslimah desa Mattoangin dalam menghadiri kegiatan PPJ ini merupakan faktor pendukung dalam kegiatan. Adapun kendala-kendala yang terjadi adalah kurangnya persiapan sehingga pemateri pertama terkesan dadakan dan waktu PPJ yang disepakati berubah dikarenakan pemateri yang terbatas sedangkan banyak dari posko lain juga mengadakan kegiatan PPJ.
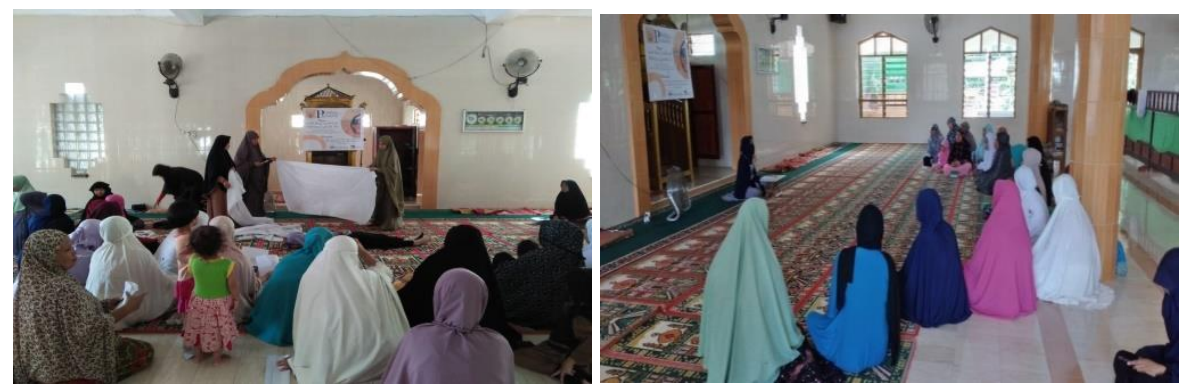

Gambar 4. Pelatihan Penyelenggaraan Jenazah untuk Muslimah 
WAHATUL MUJTAMA': Jurnal Pengabdian Masyarakat

Vol. 1, No. 2 (2020) : Hal. 129-141

Website: https://journal.stiba.ac.id

\section{5) Bakti Kesehatan Muslimah}

Bakti Kesehatan adalah salah satu progam mahasiswa KKN angkatan III tahun 2020 STIBA Makassar. Sasaran dari kegiatan ini adalah menambah wawasan para muslimah tentang kesehatan dan juga memperkenalkan tibbun nabawi. Tujuan Kegiatan ini adalah untuk meningkatkan kesadaran muslimah desa Mattoangin pentingnya menjaga kesehatan serta memperkenalkan pengobatan sesuai sunnah Rasulullah saw. Kegiatan ini juga sekaligus dimanfaatkan untuk memeriksa kondisi kesehatan muslimah desa Mattoangin

Banyak muslimah yang baru mengetahui pentingnya menjaga kesehatan. Materi yang dibawakan oleh pemateri terkait thibbun nabawi memberikan pengetahuan baru terhadap muslimah desa Mattoangin. Faktor Pendukung dalam kegiatan ini adalah tempat yang tersedia sangat memadai. Khusus kegiatan ini tidak kami adakan di masjid karena kondisi peserta yang cukup banyak. Adanya pihak-pihak luar yang membantu dalam persiapan lokasi kegiatan juga sangat mendukung terlaksananya kegiatan ini. Ditambah juga dengan pemateri yang luar biasa dalam menyampaikan pemaparan serta tim medis yang terlibat dalam kegiatan ini sangat aktif dan progresif.
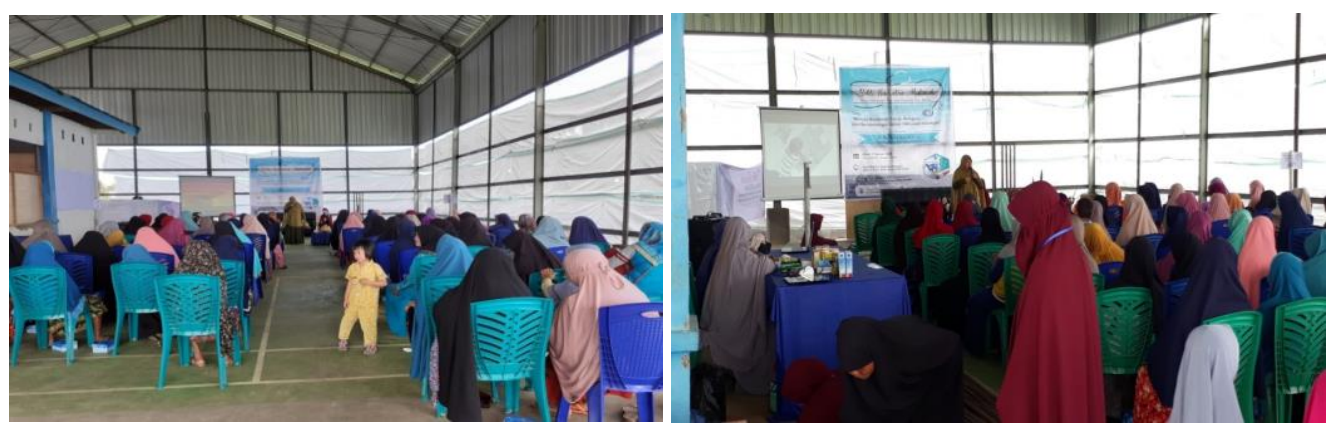

\section{Gambar 5. Bakti Kesehatan Muslimah}

\section{KESIMPULAN}

Kegiatan pengabdian masyarakat STIBA Makassar dalam bentuk pelaksanaan KKN Angkatan III, Sekolah Tinggi Ilmu Islam dan Bahasa Arab (STIBA) tahun akademik 2019/2020, yang diselenggarakan di Desa Mattoangin, Kecamatan Bantimurung, Kabupaten Maros, maka dapat ditarik kesimpulan bahwa program kerja KKN yang dapat terlaksana dengan baik dan lancar, Beberapa program dipandang sangat penting untuk di follow up setelah penarikan karena berubungan erat dengan pengembangan kualitas SDM masyarakat di Desa, secara khusus untuk kalangan Muslimah Desa Mattoangin, Kecamatan Bantimurung, Kabupaten Maros. 


\section{DAFTAR PUSTAKA}

Abdurrohman, D. (2017). Efektivitas Program Pembelajaran Taman Pendidikan AlQur'an (TPA) Dalam Meningkatkan Kemampuan Membaca Al-Qur'an di TPA AlHikmah Desa Sidosari Natar Lampung Selatan (Doctoral dissertation, UIN Raden Intan Lampung).

Hambali, H. (2017). Eksplorasi Pembelajaran Tadabbur Alam Dalam Meningkatkan Kecerdasan Naturalis (Naturalistik Intellegence) Dan Kecerdasan Spiritual (Spiritual Intellegence) Siswa SMP Unismuh Makassar. Jurnal Pendidikan Fisika, 5(1), 99-108.

Iskandar, I., \& Amirullah, M. (2020). Pelaksanaan Dirasah Qur'aniyah sebagai Upaya Peningkatan Kualitas Baca Al-Qur'an di Desa Tukamasea Kabupaten Maros. WAHATUL MUJTAMA': Jurnal Pengabdian Masyarakat, 1(1), 42-53.

Idi, A., Sukarto, T. (2006). Revitalisasi Pendidikan Islam, Yogyakarta: Tiara Wacana Istikhori, I. (2017). PEMIKIRAN ABD AL-RAHMAN AL-NAHLAWI TENTANG PENDIDIKAN MASYARAKAT BERBASIS MASJID (Studi Kitab Ushul AlTarbiyah Al-Islamiyyah wa Asalibuha: Fi Al-Bait wa Al-Madrasah wa AlMujtama). Edukasi Islami: Jurnal Pendidikan Islam, 6(02), 20.

Nurjamilah, C. (2017). Pemberdayaan Masyarakat Berbasis Masjid dalam Perspektif Dakwah Nabi saw. Journal of Islamic Studies and Humanities, 1(1), 93-119.

Priyadi, U., Syarif, H.N., Islamawati, A. (2013). Peningkat an Mutu Pembelajaran Taman Pendidikan Alquran Dengan Pembuatan Kurikulum TPA. Asian Journal of Innovation and Entrepreneurship, 2(03), 204-211.

Riswana, R. (2018). Peranan Taklim Muslimah dalam Meningkatkan Pemahaman Hak dan Kedudukan Wanita dalam Rumah Tangga (Studi pada Yayasan Markaz Imam Malik Kota Makassar) (Skripsi, Universitas Islam Negeri Alauddin Makassar).

Rodiyah, R. R. (2018). Alternatif Pemberantasan Buta Aksara Bagi Kaum Perempuan Berbasis Masjid. Jurnal Ilmiah Syi'ar, 18(2), 1-7.

Saputro, Y. E., Mansur, R., \& Mustafida, F. (2019). Peranan Majelis Taklim Waqiah Indonesia Dalam Pembinaan Akhlak Remaja Di Perumahan Joyogrand Merjosari Malang. Vicratina: Jurnal Pendidikan Islam, 4(7), 71-75.

Saddang, M., Achmad Abubakar, Munir. (2018). Implementasi Metode Dirosa Dalam Pembelajaran Al-Qur'an Dewan Pimpinan Daerah Wahdah Islamiyah Makassar. Jurnal Diskursus Islam, 6(3), 481-500. 
Suretno, S., Zakaria, A., Pardian, A., \& Ginawan, I. (2020). Implementasi Pendidikan Masyarakat Berbasis Masjid di Islamic Center Palm Raya Melalui Kegiatan Pengabdian Kepada Masyarakat di Kelurahan Bubulak, Kecamatan Bogor Barat, Kota Bogor. Khidmatul Ummah: Jurnal Pengabdian Kepada Masyarakat, 1(01), 6683.

Syafe'i, M. (2016). Masjid dalam perspektif sejarah dan hukum Islam. Online).(http://file. upi. $\quad$ edu/Direktori/FPIPS/M_K_D_U/195504281 988031MAKHMUD_SYAFE'I/MASJID_DALAM_PRESPEKTIF_SEJA RAH_DAN_HUKUM_ISLAM_(10_HALAMAN).pdf).

Taufiqurrochman, R. (2016). "Pendidikan Masyarakat Berbasis Masjid, Jurnal Jurusan Pendidikan Bahasa Arab", Fakultas Ilmu Tarbiyah dan Keguruan UIN Maulana Malik Ibrahim Malang. retrieved from http://repository.uinmalang.ac.id/799/2/masjid.pdf (diakses pada, 20 Oktober 2020).

Zakiyyah, Z., \& Haqq, A. A. (2018). Strategi Dakwah Bil Hal Dalam Program Posdaya Berbasis Masjid. ORASI: Jurnal Dakwah dan Komunikasi, 9(1), 127-143. 